\title{
Gender and Public Goods Provision in Tamil Nadu's Village Governments
}

\author{
Kiran Gajwani and Xiaobo Zhang*
}

\begin{abstract}
Using data from 144 village-level governments in India's Tamil Nadu state, we investigate political reservations for women and whether the gender of village government leaders influences the provision of village public goods. A knowledge test of village government presidents and a survey about the interaction between village presidents and higher-level officials reveal that female village government presidents have much lower knowledge of the village government system than do their male counterparts and have significantly less contact with higher-level government officials. Although male and female presidents provide similar amounts of some public goods, we find strong evidence that village governments led by a woman built fewer schools and roads-two public goods that require relatively more contact and coordination with higher-level officials. JEL codes: $\mathrm{H} 4, \mathrm{O} 1$
\end{abstract}

The role of women in developing country governance has received much attention in recent years. Today, 57 countries have quotas for women specified in their constitution or in national legislation; this figure increases to 94 when including countries with voluntary political party quotas. ${ }^{1}$ Gender equality is also one of the eight Millennium Development Goals, and the World Bank has put

* Kiran Gajwani (corresponding author) is a Lecturer/Advisor in the Economics Department, Harvard University, Cambridge, MA. E-mail: kgajwani@fas.harvard.edu. Xiaobo Zhang is a Professor at the National School of Development, Peking University, China and a Senior Research Fellow at the International Food Policy Research Institute, Washington DC. E-mail: x.zhang@cgiar.org. We thank C. Ramasamy, S. D. Sivakumar, Uma Krishnasamy, and the entire Tamil Nadu Agricultural University research team for their hard work in organizing and carrying out the data collection. We are very grateful to Ravi Kanbur for his comments and assistance throughout the preparation of this paper. Our sincere thanks also go to Nancy Chau, Stefan Klonner, Jordan Matsudaira, Ganga Shreedhar, David Newhouse, Sudha Narayanan, seminar participants at IFPRI, Cornell University, and the IFPRI-Kiel Workshop on Government Decentralization Research, and Stephen Chong, Kerry Papps, Paul Goldsmith-Pinkham, and Will Dobbie for their technical assistance with Stata. Any errors are our own. A supplemental appendix to this article is available at http://wber.oxfordjournals.org. This work was supported by the International Food Policy Research Institute.

1. From the database at http://www.quotaproject.org. These statistics include countries with quotas at national or sub-national levels. Political party quotas are only used in places with a proportional representation system, as opposed to first-past-the-post. These figures do not account for non-compliance issues.

THE WORLD BANK ECONOMIC REVIEW, VOL. 29, NO. 2, pp. 234-261

doi:10.1093/wber/lhu001

Advance Access Publication March 27, 2014

(C) The Author 2014. Published by Oxford University Press on behalf of the International Bank for Reconstruction and Development / THE WORLD BANK. All rights reserved. For permissions, please e-mail: journals.permissions@oup.com 
gender empowerment high on their agenda, stating that gender inequality hinders development and poverty reduction (World Bank 2001).

One key motivation for the reservation of government seats for women is to address the exceptionally poor status of women in developing countries. Among the poorest individuals in the developing world, women are particularly worse off in terms of health, income, job opportunities, rights, and political representation. Political reservations are one way to attempt to improve the status of women in society and ensure their participation in government. Women's wellbeing also affects others, especially their children. Political reservations thus also aim to lead to more pro-women policies, which may include pro-child, profamily, and pro-health policies. Understanding the performance of women who hold reserved seats, therefore, becomes of utmost importance. To this end, we investigate women's political reservations in village governments in India's Tamil Nadu state and whether the gender of political leaders influences public goods provision.

The impact of women's reservation policies has been hotly contested in both policy and academic arenas, largely because of a lack of counterfactuals. India's large-scale political reservations provide an excellent setting for evaluating the impact of reservation policies; the evidence, however, is mixed. ${ }^{2}$ Chattopadhyay and Duflo (2004) undertake, to our knowledge, the first major attempt to empirically analyze the effect of women politicians in India by exploiting the randomness some Indian states use in implementing reservation policies. Using data on female presidents and public goods provision in village level governments (called gram panchayats, henceforth GPs) combined with data on women's preferences, the authors show that female GP presidents (known as pradhans in some states) in women-reserved seats invest more in public goods considered important by women, such as drinking water and roads in West Bengali GPs and drinking water in Rajasthani GPs. Duflo and Topalova (2004) find a positive impact on public goods provision in women-headed GPs; however, they also find that citizens in GPs with women presidents are generally more dissatisfied with public goods provision and perceive these women to be ineffective leaders. ${ }^{3}$ In their empirical analysis of West Bengal's GPs, Beaman et al. (2009) provide evidence that this 'perception bias' fades over time with repeated exposure to female leaders. They additionally find evidence that GPs with prior female president reservations have significantly more women in unreserved GP-level elected seats, suggesting that reservations may improve the electoral potential of women. Beaman et al. (2010) build on each of these three papers by examining villages in West Bengal over an additional GP election cycle as well as a panel of 11 Indian states. They

2. Mansuri and Rao (2013) provide an excellent discussion of the literature on women's political reservations-particularly in India-and their impacts on participation in government as well as public goods provision.

3. Duflo and Topalova (2004) assume that reservations at the GP level are randomly assigned in all states in their analysis. However, many states-including states in their sample-use population ratios to assign reservations. 
confirm the main findings of these papers in addition to showing that women GP presidents from Chattopadhyay and Duflo (2004) perform even better over time: in the second election cycle analyzed, women presidents engaged in more repairs of schools and health centers and investments in irrigation facilities. In the 11 states overall, they find that women perform better for some public goods. However, they do not report how this varies across states. Village citizens might also be impacted by a role model effect of women GP presidents: Beaman et al. (2012) identify a shrinking gender gap between boys' and girls' aspirations, as well as parents' aspirations for their sons and daughters, in GPs reserved for women for two election cycles in one district in West Bengal.

In contrast, Ban and Rao (2008) examine four states in southern India and find that female presidents do not provide public goods in line with their preferences, nor do they provide fewer public goods than men. Rajaraman and Gupta (2012) show that GP expenditures on water-related issues (a women-preferred public good, as found in some previous studies) are unaffected by the GP president's gender but are significantly higher in GPs with characteristics associated with more water-borne diseases outbreaks. Bardhan et al. (2005) find mixed results in West Bengal regarding the impact of women GP president reservations on program targeting by the GP: women in reserved seats do better in bringing IRDP credit programs to the poor ${ }^{4}$ but fare worse regarding employment programs, construction of new concrete roads, and raising non-tax revenue. Although Bardhan et al. (2005) cite the difficulty in aggregating these results into an overall impact on welfare, they estimate that women-reserved GPs may be worse off in terms of targeting the poor because the gains from improved IRDP targeting are more than offset by the losses from worse employment-program targeting. Scheduled Caste (SC) and Scheduled Tribe (ST) households in womenreserved GPs are particularly negatively affected, and this effect is worse in GPs with higher land inequality among SC and ST households. Using the same set of West Bengali GPs as Bardhan et al. (2005) but in a later time period (19982004), Bardhan et al. (2010) find no evidence of improved targeting to the poor in female-reserved GPs. They do find a negative effect of women's reservation on targeting to SC and ST households; however, in contrast to their previous study, the negative impact of women in reserved GPs on poorer targeting to SC and ST households is lessened in GPs with higher land inequality. Ban and Rao (2008) and Beaman et al. (2010) find lower job-related knowledge among women GP presidents. However, the disparity between men and women presidents in Beaman et al. (2010) disappears two years into their term in office. Clearly, the empirical findings on the impact of women's GP reservations are mixed.

In this paper, we investigate public goods provision by male and female GP presidents in Tamil Nadu. Although the methodology of this paper is similar to

4. IRDP (Integrated Rural Development Programme) credit is an Indian government program that gives poor rural families access to credit and/or skills training so they can engage in income-generating activities. 
that of Chattopadhyay and Duflo (2004) and Ban and Rao (2008), we contribute to the literature on the effectiveness of women in India's village governments by building on previous work ${ }^{5}$ in the following ways. (1) We analyze the results of a knowledge test of GP rules and regulations, given to GP presidents in the fourth year of their presidency. ${ }^{6}(2)$ We incorporate data on the frequency of interaction between GP presidents and key individuals in other tiers of sub-state governance in Tamil Nadu to understand the extent of woman GP presidents' activity and connections while holding office. ${ }^{7}$ (3) We discuss important differences in the history of local governance in India's states, which may explain why our findings differ from some previous findings, particularly in West Bengal. Context is extremely important in examining women's reservations, and findings in one area cannot be assumed to hold in other areas. (4) We develop a detailed village-level dataset for two time periods using village-level government records instead of recall data on public goods, as in some previous studies. This allows for a more precise difference-in-differences (DID) analysis. We also use several outcome variables to measure public goods provision by the GP, allowing us to check the robustness of our results.

We find that female GP presidents are much less knowledgeable than are male presidents regarding the GP president position and the Panchayat system in general. Additionally, female presidents have significantly less contact with higher-level government officials vis-à-vis their male counterparts. This is important because contact and coordination with higher-level officials is necessary for certain village public goods. The results of our analysis strongly suggest that female presidents provide their GPs with fewer schools and roads, two public goods that require more connection with higher-level officials in the panchayat system. To the best of our knowledge, these results are new in the literature. We also find weak evidence that women provide fewer household toilet connections, household drinking water connections, and streetlights. For all other public goods, there is generally no statistically significant difference between provision by male and female presidents. Given the low level of public goods and infrastructure in these GPs, we consider more public goods provision to be indicative of "better" performance as a GP president.

In the next section, we briefly review the history of local governance in India, specifically in Tamil Nadu. We then present our field survey and empirical strategy for estimating the effect of president gender on village public goods provision. In the final two sections, we discuss our findings and offer some concluding thoughts.

5. We focus on the literature examining decentralized governance in India. There are numerous analyses of decentralization and public goods provision in other countries. See, for example, Zhang and Zhou (1998), Faguet (2004), and Zhang et al. (2004).

6. Our knowledge test questions focus on GP functioning and panchayat rules and thus differ from the knowledge assessments in Ban and Rao (2008) and Beaman et al. (2010).

7. In assessing interaction with higher-level officials, Ban and Rao (2008) use only a binary measure of whether a GP president has met with any higher panchayat official. 


\section{SETTING}

Self-governing village communities in India seem to have existed since two to three thousand years ago (Mathew 2000b). Village governance weakened during British rule in India but then strengthened following independence in 1947, motivated by Gandhi's vision of strong decentralized governments. ${ }^{8}$ Although some form of local governance existed in many states, the structure, duties, reservation policies, and consistency of elections varied widely across states. Uniformity of decentralization across states was largely advanced in the early 1990s through the 73rd and 74th Constitutional Amendments. The 73rd Amendment, which focuses on decentralization in rural areas, ${ }^{9}$ required the creation of three tiers of sub-state governance-called panchayats-at the district, block (or union), and village levels in each of India's 28 states. ${ }^{10}$ The 73rd Amendment notably calls for the reservation of seats at all levels of panchayats for women, Scheduled Caste (SC), and Scheduled Tribe (ST) persons. ${ }^{11}$

Village panchayats, known as gram panchayats (GPs), have recently received much attention in the literature due to their use of political reservations. A minimum of one-third of GP presidents' seats within each state must be reserved for women, and another portion is reserved for SC and ST persons based on the composition of SC and ST persons within the state. These mandatory reservations are well suited for empirically analyzing the role of GPs in public goods provision and the extent of influence of the GP president. ${ }^{12}$

Our study focuses on Tamil Nadu, India's southernmost state. Tamil Nadu was originally part of the Madras State after India's independence and became present-day Tamil Nadu in 1968. Aram and Palanithurai (2000) provide a summary of the rich history of local governance in Tamil Nadu. ${ }^{13}$ During the peak of the Chola Dynasty (roughly 900-1200 AD), villages were strong, selfgoverning units. Local governance was also reasonably strong during the colonial period, though it weakened in the final years before independence. Through the Madras Panchayat Act of 1958, local governance strengthened, and Tamil Nadu was a panchayat success story. However, from the 1970s to the mid-1980, things were in flux. After the passage of India's 73rd Constitutional Amendment, Tamil Nadu created the 1994 Tamil Nadu Panchayats Act, which included women's reservations. Its first post-Act panchayat elections were held in 1996 and have since been held every five years.

8. For a brief history of local governments in each of India's states, see Mathew (2000a).

9. The 74th Amendment applies to municipalities.

10. India's seven Union Territories are headed by a federal government-appointed administrator.

11. "Scheduled Caste" refers to persons historically found at the bottom of India's caste system of social hierarchy, formerly referred to as "Untouchables."

12. Reservation of seats for women and SC and ST persons is required for all elected positions in the three tiers of panchayats; we focus solely on the position of GP president.

13. All historical information about Tamil Nadu's governance in this paragraph comes from Aram and Palanithurai (2000). 
The $73^{\text {rd }}$ Amendment outlines 29 areas that can be allocated to the GP; each state then chooses which areas it will devolve. The Amendment also sets requirements on the reservation of seats, but each state can implement this in its own way. In Tamil Nadu, the Rural Development and Panchayati Raj Department of the Government of Tamil Nadu is responsible for the Tamil Nadu Panchayats Acts of 1994 as well as many other documents and government orders outlining the rules of the panchayat system and what is devolved to the GP. ${ }^{14}$ GP reservations in Tamil Nadu are held for 10 years (two five-year election terms), and the selection of GPs for reservation-for women, SC, and ST persons-is performed at the block level. Tamil Nadu, similar to many Indian states, does not randomly select GPs for women, SC, and ST reservations. For the 1996 elections (the first elections following the Tamil Nadu Panchayats Act), one-third of GPs in each block were reserved for women, and 20 percent were reserved for SC and ST presidents. Reserved GPs are chosen as follows:

(1) All GPs within a block are arranged in descending order of the ratio of SC persons to the total population. The top 20 percent are set aside for SC and ST reservations.

(2) If the ST population in a block is above a certain level, one GP is reserved for an ST president. If not, all SC and ST reservations chosen in part (1) are set for SC reservation. ${ }^{15}$

(3) The GPs in the 20 percent reserved for SC/ST reservations are arranged in descending order of the ratio of female SC persons to the total SC population. The top one-third is reserved for female SC presidents.

(4) The remaining GPs are sorted in descending order of the ratio of females to the total population. The top one-third is reserved for female presidents.

(5) All reservations are held for 10 years (two terms). After 10 years, the same procedure is implemented, except that GPs previously reserved for SC and ST presidents are excluded from step (1), and GPs previously reserved for women are excluded from step (4).

Given this reservation method, a regression discontinuity (RD) approach would be ideal for identifying the effect of reservations on differences in public goods provision. However, based on the available data, an $\mathrm{RD}$ analysis requires that we omit all GPs with an SC reservation, resulting in a significant loss in observations, especially because the analysis is conducted within a small bandwidth of the discontinuity. Thus, we use RD only as a check of our key findings.

Although the assignment of reservations in Tamil Nadu is not random, we believe that women's reservations are not related to any unobservable

14. Some documents are available on the Rural Development and Panchayati Raj Department website: http://www.tnrd.gov.in/acts_go.html. Many, however, are not. We obtained some documents from our field contacts to help in understanding the devolution of power and responsibility to GP presidents in Tamil Nadu.

15. No GPs in our sample were selected for ST reservation. Tamil Nadu's very small ST population means that very few GPs in Tamil Nadu are selected for ST reservation overall. 
TABLE 1. Female and SC Population Ratios by Block $($ Year $=1991)$

\begin{tabular}{llccccc}
\hline District & \multicolumn{1}{c}{ Block } & $\begin{array}{c}\text { GPs per } \\
\text { block (in } \\
\text { sample) }\end{array}$ & $\begin{array}{c}\text { Mean, } \\
\text { female/total } \\
\text { population } \\
\text { ratio }\end{array}$ & $\begin{array}{c}\text { Standard } \\
\text { deviation }\end{array}$ & $\begin{array}{c}\text { Mean, } \\
\text { SC/total } \\
\text { population } \\
\text { ratio }\end{array}$ & $\begin{array}{c}\text { Standard } \\
\text { deviation }\end{array}$ \\
\hline Coimbatore & Avinashi & 12 & 0.480 & 0.016 & 0.257 & 0.063 \\
& Gudimangalam & 12 & 0.497 & 0.011 & 0.266 & 0.065 \\
& Palladam & 12 & 0.491 & 0.013 & 0.209 & 0.056 \\
& Pollachi (North) & 12 & 0.489 & 0.014 & 0.218 & 0.092 \\
Pudukottai & Aranthangi & 12 & 0.506 & 0.012 & 0.104 & 0.076 \\
& Karambakudi & 12 & 0.498 & 0.012 & 0.271 & 0.168 \\
& Kunnandar Koil & 12 & 0.495 & 0.010 & 0.179 & 0.133 \\
& Ponnamaravathi & 12 & 0.522 & 0.016 & 0.198 & 0.115 \\
& K.V.Kuppam & 12 & 0.494 & 0.015 & 0.287 & 0.177 \\
& Kanniyambadi & 12 & 0.505 & 0.011 & 0.242 & 0.111 \\
& Natrampalli & 12 & 0.491 & 0.009 & 0.223 & 0.176 \\
& Nemeli & 12 & 0.496 & 0.012 & 0.290 & 0.174 \\
\hline
\end{tabular}

Source: Authors' analysis based on data described in text.

determinants of public goods provision on the following grounds: (i) the female-to-total population ratio is extremely similar across GPs within each block (Table 1); (ii) GPs selected for female reservation do not differ significantly from non-reserved GPs in a number of village attributes (Table 2, first three columns); ${ }^{16}$ (iii) the female-to-total population ratio is uncorrelated with any village characteristics for which we have data (Table S1.1 in the supplemental appendix, available at http://wber.oxfordjournals.org); and (iv) a t-test of the difference in mean public goods levels in 1991 (before reservation assignments were made) shows that GPs selected for female reservation in 1996 did not differ significantly from unreserved GPs in most of the 11 public goods measures used in this analysis (Table 3). Reserved GPs did have fewer public toilets; however, we do not feel that this affects our main findings. Because we use a DID approach to estimate the effect of women's GP reservations, even if unobservable factors exist that influence a GP's reservation status and affect public goods provision, our estimate of the effect of reservation on public goods provision will be unbiased as long as those factors do not change over time. We discuss this further in our empirical strategy.

\section{A TA}

The data for this study come from village government records and village-level surveys conducted in Tamil Nadu in 2005 and 2006, implemented through a

16. There is one exception: the number of Christian households is significantly greater in unreserved villages. However, Christian households comprise less than two percent of total households in our sample, so we are not concerned with this difference. 
TA b LE 2. Comparing Village Characteristics in GPs Unreserved and Reserved for Female Presidents

\begin{tabular}{|c|c|c|c|c|}
\hline Variable & $\begin{array}{l}1991 \text { Mean, } \\
\text { Unreserved GPs }\end{array}$ & $\begin{array}{l}1991 \text { Mean, } \\
\text { Reserved GPs }\end{array}$ & $\begin{array}{l}\text { Difference in } \\
1991 \text { Means }\end{array}$ & $\begin{array}{l}\text { Difference in } \\
\text { Percent Change } \\
1991 \text { to } 2005\end{array}$ \\
\hline $\begin{array}{l}\text { Village population - } \\
\text { total }\end{array}$ & 2648.622 & 2289.717 & $\begin{array}{l}358.905 \\
251.410\end{array}$ & $\begin{array}{l}0.145 \\
0.112\end{array}$ \\
\hline Female population & 1299.816 & 1153.130 & $\begin{array}{l}146.686 \\
121.847\end{array}$ & $\begin{array}{l}0.152 \\
0.108\end{array}$ \\
\hline $\begin{array}{l}\text { Scheduled Caste (SC) } \\
\text { population }\end{array}$ & 551.959 & 552.935 & $\begin{array}{r}-0.976 \\
70.585\end{array}$ & $\begin{array}{l}0.327^{*} \\
0.167\end{array}$ \\
\hline Households total & 607.592 & 533.544 & $\begin{array}{l}74.048 \\
61.262\end{array}$ & $\begin{array}{l}0.165 \\
0.112\end{array}$ \\
\hline Hindu households & 575.929 & 512.674 & $\begin{array}{l}63.255 \\
60.499\end{array}$ & $\begin{array}{l}0.174 \\
0.144\end{array}$ \\
\hline Muslim households & 19.959 & 14.870 & $\begin{array}{l}5.090 \\
4.300\end{array}$ & $\begin{array}{l}0.060 \\
0.160\end{array}$ \\
\hline Christian households & 11.704 & 6.000 & $\begin{array}{l}5.704 * * \\
2.607\end{array}$ & $\begin{array}{l}0.052 \\
0.174\end{array}$ \\
\hline Farm households & 329.845 & 303.130 & $\begin{array}{l}26.715 \\
38.818\end{array}$ & $\begin{array}{l}0.163 \\
0.125\end{array}$ \\
\hline $\begin{array}{l}\text { Village citizens } \\
\text { working in village }\end{array}$ & 594.490 & 481.804 & $\begin{array}{r}112.685 \\
74.921\end{array}$ & $\begin{array}{r}-2.317 \\
1.770\end{array}$ \\
\hline $\begin{array}{l}\text { Female village citizens } \\
\text { working in village }\end{array}$ & 271.857 & 220.696 & $\begin{array}{l}51.161 \\
35.393\end{array}$ & $\begin{array}{r}-3.878 \\
2.566\end{array}$ \\
\hline Total Land (acres) & 2227.691 & 2077.151 & $\begin{array}{l}150.540 \\
242.569\end{array}$ & $\begin{array}{l}0.141 \\
0.103\end{array}$ \\
\hline Literates & 1221.255 & 1084.391 & $\begin{array}{l}136.864 \\
132.655\end{array}$ & $\begin{array}{l}0.218 \\
0.170\end{array}$ \\
\hline
\end{tabular}

Notes: Standard errors from a t-test of a difference in means are shown in italics.

Indicates significance at $* 10 \%, * 5 \%$.

Source: Authors' analysis based on data described in text.

joint research project of the International Food Policy Research Institute (IFPRI) and Tamil Nadu Agricultural University (TNAU). ${ }^{17}$ Tamil Nadu has 29 district panchayats (DPs), 385 panchayat union councils (PUCs), and 12,618 GPs in total. To select GPs for our survey, we divided the districts of Tamil Nadu into three categories based on their Human Development Index: Developed, Moderately Developed, and Less Developed. We randomly selected one district from each of the three human development categories, from which four PUCs were randomly chosen. From each of the 12 PUCs, we randomly selected 12 GPs, for a total of 144 GPs from 12 PUCs from three districts. The three districts from which the 144 GPs for this survey were selected are Coimbatore, Pudukottai, and Vellore.

17. We also used election data posted by the Tamil Nadu State Election Commission to verify the reservation status of GPs in our study (http://tnsec.tn.nic.in). 
Table 3. Comparing Initial Public Goods Levels in GPs Unreserved and Reserved for Female Presidents (Year $=1991$ )

\begin{tabular}{|c|c|c|c|}
\hline & $\begin{array}{l}\text { Unreserved GPs } \\
\text { Mean } 1991\end{array}$ & $\begin{array}{c}\text { GPs Reserved for Women } \\
\text { Mean } 1991\end{array}$ & Difference \\
\hline Number of borewells & 3.330 & 3.780 & $\begin{array}{r}-0.451 \\
0.545\end{array}$ \\
\hline Distance to nearest borewell & 0.232 & 0.230 & $\begin{array}{l}0.002 \\
0.040\end{array}$ \\
\hline HEALTH - Composite measure & -0.017 & 0.037 & $\begin{array}{r}-0.054 \\
0.179\end{array}$ \\
\hline Distance to nearest concrete road & 0.447 & 0.364 & $\begin{array}{l}0.082 \\
0.093\end{array}$ \\
\hline Number of schools & 2.582 & 2.261 & $\begin{array}{l}0.321 \\
0.265\end{array}$ \\
\hline Number of public toilets & 0.459 & 0.304 & $\begin{array}{l}0.155^{*} \\
0.088\end{array}$ \\
\hline Number of bus and minibus trips & 8.643 & 7.674 & $\begin{array}{l}0.969 \\
1.702\end{array}$ \\
\hline Common taps & 44.133 & 48.178 & $\begin{array}{r}-4.045 \\
9.929\end{array}$ \\
\hline HH toilets & 10.980 & 7.652 & $\begin{array}{l}3.327 \\
2.844\end{array}$ \\
\hline $\mathrm{HH}$ drinking water connections & 19.061 & 16.891 & $\begin{array}{l}2.170 \\
8.285\end{array}$ \\
\hline Streetlights & 60.551 & 52.870 & $\begin{array}{l}7.681 \\
8.266\end{array}$ \\
\hline
\end{tabular}

Note: Standard errors from a t-test of a difference in means are shown in italics.

$* \mathrm{p}<.10$.

Source: Authors' analysis based on data described in text.

Data were collected using several surveys. For this analysis, the data come from individual interviews with each GP president, interviews with 270 randomly selected citizens, and a secondary data schedule used to gather current and historic data on GP characteristics and levels of public goods. Summary statistics for all data are given in Tables $4 \mathrm{a}$ and $4 \mathrm{~b}$.

\section{EMPIRICAL STRATEGY}

This study aims to examine the treatment effect of reserving the GP president's position for women by comparing reserved and unreserved GPs. However, because we can never observe a reserved GP in the absence of a reservation, estimates of the effect of reservations can be biased. Additionally, one may be concerned about the use of GP female-population ratios to determine women's reserved seats. One technique to control for potential bias caused by unobservable factors is a DID estimation strategy. 
TABLE 4a. Summary Statistics $($ Year $=1991)$

\begin{tabular}{|c|c|c|c|c|c|}
\hline Variable & Obs & Mean & $\begin{array}{l}\text { Standard } \\
\text { Deviation }\end{array}$ & Min & $\operatorname{Max}$ \\
\hline Village population - total & 144 & 2533.97 & 1411.77 & 364 & 7355 \\
\hline Female population & 144 & 1252.96 & 682.82 & 185 & 3519 \\
\hline Scheduled Caste (SC) population & 144 & 552.27 & 393.55 & 0 & 1891 \\
\hline Ratio of SC to total population & 144 & 0.23 & 0.13 & 0 & 0.67 \\
\hline Ratio of females to total population & 144 & 0.50 & 0.02 & 0.43 & 0.55 \\
\hline Households - total & 144 & 583.94 & 343.32 & 75 & 1892 \\
\hline Hindu households & 144 & 555.72 & 338.61 & 53 & 1863 \\
\hline Muslim households & 144 & 18.33 & 24.09 & 0 & 113 \\
\hline Christian households & 144 & 9.88 & 14.78 & 0 & 100 \\
\hline Farm households & 143 & 321.25 & 216.43 & 31 & 1260 \\
\hline Total land (acres) & 144 & 2179.60 & 1354.29 & 281.70 & 5719 \\
\hline Village citizens working in village & 144 & 558.49 & 421.04 & 5 & 1757 \\
\hline Female village citizens working in village & 144 & 255.51 & 198.78 & 0 & 985 \\
\hline Literates & 144 & 1177.54 & 742.39 & 160 & 3436 \\
\hline Number of schools & 144 & 2.48 & 1.49 & 1 & 10 \\
\hline Distance to nearest concrete road & 144 & 0.42 & 0.52 & 0 & 5 \\
\hline Number of bus and minibus trips & 144 & 8.33 & 9.50 & 0 & 60 \\
\hline Streetlights & 144 & 58.10 & 46.23 & 0 & 270 \\
\hline Number of public toilets & 144 & 0.41 & 0.49 & 0 & 1 \\
\hline Common taps & 143 & 45.41 & 54.98 & 0 & 425 \\
\hline Number of borewells & 139 & 3.46 & 2.93 & 0 & 14 \\
\hline HH toilets & 144 & 9.92 & 15.93 & 0 & 82 \\
\hline HH drinking water connections & 144 & 18.37 & 46.20 & 0 & 325 \\
\hline $\begin{array}{l}\text { Percentage of children under } 6 \text { with DPT } \\
\text { vaccine }\end{array}$ & 144 & 0.21 & 0.21 & 0.04 & 1.36 \\
\hline $\begin{array}{l}\text { Percentage of children under } 6 \text { with BCG } \\
\text { vaccine }\end{array}$ & 144 & 0.21 & 0.21 & 0.03 & 1.36 \\
\hline $\begin{array}{l}\text { Percentage of children under } 6 \text { with OPV } \\
\text { vaccine }\end{array}$ & 144 & 0.22 & 0.23 & 0 & 1.43 \\
\hline $\begin{array}{l}\text { Percentage of children under } 6 \text { with } \\
\text { measles vaccine }\end{array}$ & 144 & 0.20 & 0.22 & 0.04 & 1.56 \\
\hline $\begin{array}{l}\text { Percentage of children under } 6 \text { with TT } \\
\text { vaccine }\end{array}$ & 144 & 0.30 & 0.30 & 0.05 & 2.11 \\
\hline GP reserved for woman & 144 & - & - & - & - \\
\hline GP president's age & 144 & - & - & - & - \\
\hline GP president member of AIADMK & 143 & - & - & - & - \\
\hline GP president test score (out of 19) & 144 & - & - & - & - \\
\hline $\begin{array}{l}\text { Frequency of contact with Block } \\
\text { Development Officer }\end{array}$ & 144 & - & - & - & - \\
\hline $\begin{array}{l}\text { Frequency of contact with Panchayat } \\
\text { Union Chairman }\end{array}$ & 144 & - & - & - & - \\
\hline $\begin{array}{l}\text { Frequency of contact with District } \\
\text { Panchayat Chairman }\end{array}$ & 144 & - & - & - & - \\
\hline Number of villages in GP & 144 & - & - & - & - \\
\hline
\end{tabular}

Note: Since the first GP elections in accordance with the 73rd Amendment took place in 1996, GP president-specific information is for 2005 only.

Source: Authors' analysis based on data described in text. 
Table 4 b. Summary Statistics (Year $=2005)$

\begin{tabular}{|c|c|c|c|c|c|}
\hline Variable & Obs & Mean & $\begin{array}{l}\text { Standard } \\
\text { Deviation }\end{array}$ & Min & $\operatorname{Max}$ \\
\hline Village population - total & 144 & 3120.21 & 2135.04 & 344 & 15420 \\
\hline Female population & 144 & 1558.88 & 1043.27 & 170 & 7353 \\
\hline Scheduled Caste $(\mathrm{SC})$ population & 144 & 655.89 & 471.32 & 0 & 2296 \\
\hline Ratio of SC to total population & 144 & 0.23 & 0.13 & 0 & 0.70 \\
\hline Ratio of females to total population & 144 & 0.50 & 0.02 & 0.43 & 0.57 \\
\hline Households - total & 144 & 735.88 & 515.74 & 68 & 4287 \\
\hline Hindu households & 144 & 693.61 & 504.60 & 45 & 4187 \\
\hline Muslim households & 144 & 26.58 & 37.71 & 0 & 261 \\
\hline Christian households & 144 & 15.69 & 22.73 & 0 & 150 \\
\hline Farm households & 144 & 365.44 & 262.04 & 35 & 1725 \\
\hline Total land (acres) & 142 & 2086.79 & 1318.02 & 223.50 & 5729.40 \\
\hline Village citizens working in village & 144 & 861.88 & 681.83 & 2 & 3780 \\
\hline Female village citizens working in village & 144 & 399.58 & 339.60 & 2 & 2220 \\
\hline Literates & 144 & 1853.95 & 1359.26 & 184 & 10188 \\
\hline Number of schools & 144 & 3.30 & 2.14 & 1 & 13 \\
\hline Distance to nearest concrete road & 144 & 0.25 & 0.38 & 0 & 3.00 \\
\hline Number of bus and minibus trips & 144 & 13.22 & 14.38 & 0 & 80 \\
\hline Streetlights & 144 & 100.66 & 70.41 & 0 & 451 \\
\hline Number of public toilets & 144 & 1.75 & 1.62 & 0 & 10 \\
\hline Common taps & 144 & 84.48 & 74.65 & 0 & 430 \\
\hline Number of borewells & 139 & 6.74 & 5.08 & 0 & 31 \\
\hline $\mathrm{HH}$ toilets & 144 & 129.70 & 203.83 & 0 & 1750 \\
\hline $\mathrm{HH}$ drinking water connections & 144 & 125.96 & 150.95 & 0 & 900 \\
\hline $\begin{array}{l}\text { Percentage of children under } 6 \text { with DPT } \\
\text { vaccine }\end{array}$ & 144 & 0.31 & 0.29 & 0.03 & 1.90 \\
\hline $\begin{array}{l}\text { Percentage of children under } 6 \text { with BCG } \\
\text { vaccine }\end{array}$ & 144 & 0.30 & 0.30 & 0.02 & 1.84 \\
\hline $\begin{array}{l}\text { Percentage of children under } 6 \text { with OPV } \\
\text { vaccine }\end{array}$ & 144 & 0.32 & 0.31 & 0.03 & 1.90 \\
\hline $\begin{array}{l}\text { Percentage of children under } 6 \text { with } \\
\text { Measles vaccine }\end{array}$ & 144 & 0.30 & 0.30 & 0.03 & 1.88 \\
\hline $\begin{array}{l}\text { Percentage of children under } 6 \text { with TT } \\
\text { vaccine }\end{array}$ & 144 & 0.44 & 0.40 & 0.04 & 2.33 \\
\hline GP reserved for woman & 144 & 0.32 & 0.47 & 0 & 1 \\
\hline GP president's age & 144 & 47.00 & 8.86 & 27 & 68 \\
\hline GP president member of AIADMK & 143 & 0.60 & 0.49 & 0 & 1 \\
\hline GP president test score (out of 19) & 144 & 11.76 & 3.00 & 5 & 18 \\
\hline $\begin{array}{l}\text { Frequency of contact with Block } \\
\text { Development Officer"* }\end{array}$ & 144 & 2.75 & 0.47 & 1 & 3 \\
\hline $\begin{array}{l}\text { Frequency of contact with Panchayat } \\
\text { Union Chairman* }\end{array}$ & 144 & 1.74 & 1.00 & 0 & 3 \\
\hline $\begin{array}{l}\text { Frequency of contact with District } \\
\text { Panchayat Chairman* }\end{array}$ & 144 & 1.01 & 0.76 & 0 & 3 \\
\hline Number of villages in GP & 144 & 6.26 & 4.68 & 1 & 39 \\
\hline
\end{tabular}

Notes: *"Frequency of Contact with. .." was a question posed to GP presidents. $0=$ "never," $1=$ "rarely," 2 = "sometimes," and $3=$ "frequently."

Source: Authors' analysis based on data described in text. 
DID estimation uses a control group and an experimental group and observations in at least two time periods: one before the 'change' and one after. The benefit of using DID is that even if there are unobservable factors that influenced a GP's reservation status and could affect public goods provision, our estimate of the effect of reservation on public goods provision will be unbiased if those factors do not change differently over time in reserved and unreserved GPs.

In its most general form, the DID estimator compares the change over time between the two groups. Consider unreserved (U) and reserved (R) GPs and the time periods 1991 (before the $73^{\text {rd }}$ Amendment policies were instituted in Tamil $\mathrm{Nadu}$ ) and 2005 (the fourth year of a Tamil Nadu GP president's term in office, which is the ninth year of a 10 -year reservation cycle). ${ }^{18}$ In this case, the DID estimator is given by

DîD $=\left(\overline{\mathrm{Y}}_{\mathrm{R}, 2005}-\overline{\mathrm{Y}}_{\mathrm{R}, 1991}\right)-\left(\overline{\mathrm{Y}}_{\mathrm{U}, 2005}-\overline{\mathrm{Y}}_{\mathrm{U}, 1991}\right)$

where $Y$ is the dependent variable of interest (public goods), group $R$ consists of reserved GPs, group $U$ consists of unreserved GPs, and $\bar{Y}_{g, t}$ is the mean value of $Y$ for group $g$ and time $t$. The DID estimator can also be obtained from a regression of the form

$\mathrm{Y}_{\text {it }}=\alpha+\beta_{1}$ RESERVED $_{\mathrm{i}}+\beta_{2}$ AFTER $_{\mathrm{t}}+\beta_{3}\left(\right.$ RESERVED $_{\mathrm{i}}^{*}$ AFTER $\left._{\mathrm{t}}\right)+\varepsilon_{\text {it }}$

for GP $i$ in time period $t$, where RESERVED is a dummy variable equaling 1 for reserved GPs and AFTER is a dummy variable equaling 1 for observations occurring in 2005, after Tamil Nadu's reservation policy was implemented. $\hat{\beta}_{3}$ is the DID estimate. In a fixed effects estimation, RESERVED is dropped.

An unbiased estimate of $\beta_{3}$ from Equation (2) requires that any unobservable factors that influence whether a GP received treatment and affect the GP's public goods outcomes have a similar trend over time in reserved and unreserved GPs. For example, if, over time, GPs with higher female population ratios have a different rate of change in political party affiliations and if political party affiliations impact public goods provision, then our estimates could be biased. We provide some evidence of similar trends in reserved and unreserved GPs by comparing the change in village characteristics over 1991-2005 (Table 2, rightmost column). We see no statistically significant difference in the change in village characteristics over the 1991-2005 period for any variables except for the SC population. Although the rate of growth in the SC population was greater in GPs that were unreserved in 2005, we do not think this is a major cause for concern for two reasons. First, the SC population in two unreserved GPs increased by more than 600 percent from 1991-2005, growing from 23 to 192 and 64 to

18. Data on public toilets, household toilets, and buses and minibuses are from 1995 and 2004. Because 1996 was the first year of reservation, these years are suitable for the analysis, as they provide data from before reservation and from the eighth year of the reservation. 
465. There are also four other unreserved GPs whose SC populations grew by more than 150 percent. Excluding these huge growers causes the statistical significance to disappear. Second, there is anecdotal evidence that with the advent of SC reservations and other SC affirmative action-type programs, more people are claiming SC status or are no longer denying their SC status (Anand and Sharma 2011). This phenomenon might explain the observed difference in the SC population.

We further refine our DID estimation to include covariates, so our estimates will still be accurate even if there are different trends in the SC population or other variables. The DID estimate in this case is given by $\hat{\gamma}_{3}$ of the following regression:

$\mathrm{Y}_{\mathrm{it}}=\alpha+\gamma_{1}$ RESERVED $_{\mathrm{i}}+\gamma_{2}$ AFTER $_{\mathrm{t}}+\gamma_{3}\left(\right.$ RESERVED $_{\mathrm{i}}^{*}$ AFTER $\left._{\mathrm{t}}\right)+\boldsymbol{\gamma} \mathrm{X}+\boldsymbol{\varepsilon}_{\mathrm{it}}$,

where X contains covariates such as the GP's female and SC population ratios in 1991 (i.e., the values on which the reservations are based). ${ }^{19}$

\section{The Analysis}

Of the 144 villages in our survey, 47 have GPs with presidential seats reserved for women, ${ }^{20}$ which perfectly represents India's requirement that one-third of GP president seats be reserved for women. Only one GP failed to comply with the reservation policy by seating a male president, leaving 46 women-led GPs in our analysis. The women presidents are 42 years of age on average (ranging from 27 to 65 ), and 61 percent cite farming as their primary occupation. Thirty-nine percent of the women cite the reservation of the presidential seat as their primary motivation for running for office, 33 percent cite past work with the community as their motivation, and 28 percent cite 'other' reasons. There are no women presidents in unreserved GPs.

Tamil Nadu is a leader in women's empowerment in India, and this is reflected by the high literacy rate for women: 64 percent, compared to the all-India female literacy rate of 54 percent. $^{21}$ The education level of female presidents in our sample is also very comparable to that of male presidents: 47 and 41 percent of male and female GP presidents, respectively, have at least a high school education, and 82 and 74 percent have at least a middle-school education. However, on a knowledge test ${ }^{22}$ of the GP president's duties and the panchayat system in

19. Because we perform a fixed-effects regression, time-invariant covariates (such as 1991 population ratios) are interacted with a time dummy (i.e., AFTER). A more intuitive way to think about this is as a cross-sectional regression of the form $y D_{I F F_{i}}=\gamma+\delta_{1} R E S E R V E D_{i}+\delta \boldsymbol{X}+\eta_{i}$, where $y$ DIFF is the change in the amount of public good $y$ from 1991 to 2005 and $\hat{\delta}_{1}$ is the DID estimate.

20. In a previous version of this paper, we cited different reservation statistics. This was the result of a data entry error, which has been checked and rectified in this paper.

21. These statistics come from the 2001 Census.

22. The 19 questions on the knowledge test are given in Appendix A1. 
Figure 1. Results of a 19-Question Knowledge Test Given to GP Presidents

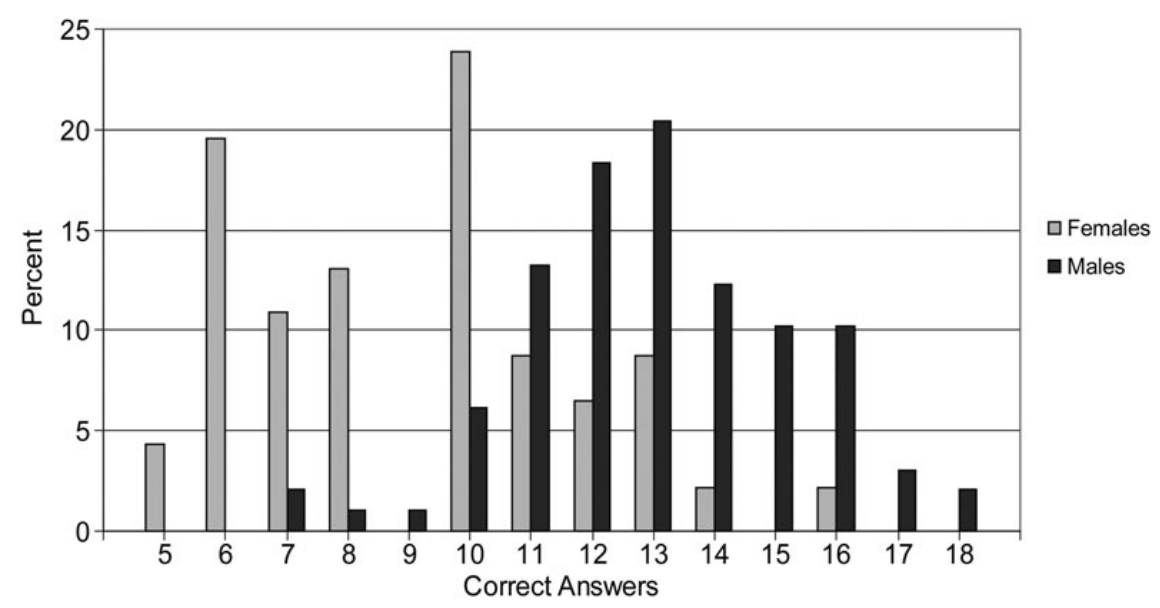

Source: Authors' analysis based on data described in text.

general that was given to presidents during the individual interviews, female presidents scored much lower than their male counterparts (Figure 1). For example, only 28 percent of female presidents in women-reserved GPs answered at least 11 of the 19 questions correctly, compared to 90 percent of male presidents. Gender strongly predicts presidents' test scores even after controlling for presidents' age, whether this is their second term, education, income, caste, religion, political party affiliation, and motivation for running for office (Table 5). The correlation between gender and test scores is not only strongly significant but of large magnitude as well. Given such poor knowledge of the GP, we might expect the performance of female presidents in women-reserved GPs to suffer. In particular, we might expect to see fewer public goods provided by female presidents in women-reserved GPs because the GP president plays a key role in procuring public goods for the GP. This knowledge disparity is much more pronounced than Beaman et al. (2010) find in West Bengal. Additionally, this GP knowledge gap among women GP presidents in Tamil Nadu exists the fourth year into their term in office.

Reserved-female presidents also have much less contact with higher-level officials (Table 6). These findings are significant at the one percent level and represent substantial differences in contact for all three higher-level officials. To fund projects within a GP, the GP president must be in contact with higher-level officials to apply for funds through government schemes administered at higher levels. According to our survey team's observations, the main function of the GP president is to identify needs and take the necessary steps to mobilize funds. Only very low-cost village projects can be undertaken by the GP president without consultation with higher-level officials. The most important person with whom Tamil Nadu's GP presidents must be in contact is the Block Development Officer 
Table 5. Predicting Test Scores

Dependent Variable for all Regressions: President's Knowledge Test Score

\begin{tabular}{|c|c|c|c|c|c|c|}
\hline $\begin{array}{l}\text { President } \\
\text { Characteristics }\end{array}$ & (1) & (2) & (3) & (4) & $(5)$ & (6) \\
\hline Gender & $\begin{array}{c}-3.457 * * * \\
(0.483)\end{array}$ & $\begin{array}{c}-3.480 * * * \\
(0.470)\end{array}$ & $\begin{array}{c}-3.472 * * * \\
(0.473)\end{array}$ & $\begin{array}{c}-3.310 * * * \\
(0.477)\end{array}$ & $\begin{array}{c}-3.380 * * * \\
(0.481)\end{array}$ & $\begin{array}{c}-3.199 * * * \\
(0.474)\end{array}$ \\
\hline Primary school & $\begin{array}{r}-0.470 \\
(1.247)\end{array}$ & $\begin{array}{r}-0.428 \\
(1.202)\end{array}$ & $\begin{array}{r}-0.419 \\
(1.206)\end{array}$ & $\begin{array}{r}-1.044 \\
(1.215)\end{array}$ & $\begin{array}{r}-1.064 \\
(1.207)\end{array}$ & $\begin{array}{r}-0.814 \\
(1.121)\end{array}$ \\
\hline Middle school & $\begin{array}{c}0.725 \\
(1.169)\end{array}$ & $\begin{array}{c}0.857 \\
(1.128)\end{array}$ & $\begin{array}{c}0.864 \\
(1.131)\end{array}$ & $\begin{array}{c}0.140 \\
(1.183)\end{array}$ & $\begin{array}{c}0.159 \\
(1.163)\end{array}$ & $\begin{array}{c}0.463 \\
(1.069)\end{array}$ \\
\hline High school & $\begin{array}{c}1.044 \\
(1.165)\end{array}$ & $\begin{array}{c}1.159 \\
(1.117)\end{array}$ & $\begin{array}{c}1.143 \\
(1.121)\end{array}$ & $\begin{array}{c}0.465 \\
(1.163)\end{array}$ & $\begin{array}{c}0.447 \\
(1.137)\end{array}$ & $\begin{array}{c}0.923 \\
(1.056)\end{array}$ \\
\hline $\begin{array}{l}\text { Higher } \\
\text { secondary }\end{array}$ & $\begin{array}{c}0.945 \\
(1.451)\end{array}$ & $\begin{array}{c}1.276 \\
(1.428)\end{array}$ & $\begin{array}{c}1.284 \\
(1.433)\end{array}$ & $\begin{array}{r}0.569 \\
(1.566)\end{array}$ & $\begin{array}{c}0.734 \\
(1.545)\end{array}$ & $\begin{array}{c}1.455 \\
(1.500)\end{array}$ \\
\hline College & $\begin{array}{l}2.269 * \\
(1.302)\end{array}$ & $\begin{array}{l}2.511 * * \\
(1.259)\end{array}$ & $\begin{array}{l}2.519 * * \\
(1.263)\end{array}$ & $\begin{array}{c}1.700 \\
(1.308)\end{array}$ & $\begin{array}{c}1.507 \\
(1.307)\end{array}$ & $\begin{array}{c}1.951 \\
(1.213)\end{array}$ \\
\hline Age & $\begin{array}{c}0.041 * \\
(0.023)\end{array}$ & $\begin{array}{c}0.043 * \\
(0.023)\end{array}$ & $\begin{array}{c}0.042 * \\
(0.024)\end{array}$ & $\begin{array}{c}0.028 \\
(0.024)\end{array}$ & $\begin{array}{c}0.031 \\
(0.024)\end{array}$ & $\begin{array}{c}0.029 \\
(0.024)\end{array}$ \\
\hline Second term & $\begin{array}{c}1.275 \\
(0.838)\end{array}$ & $\begin{array}{l}1.324 * \\
(0.798)\end{array}$ & $\begin{array}{l}1.333 * \\
(0.801)\end{array}$ & $\begin{array}{l}1.292 \% \\
(0.732)\end{array}$ & $\begin{array}{l}1.393 * \\
(0.732)\end{array}$ & $\begin{array}{l}1.663 * * \\
(0.774)\end{array}$ \\
\hline SC & & $\begin{array}{c}0.782 \\
(0.546)\end{array}$ & $\begin{array}{c}0.790 \\
(0.549)\end{array}$ & $\begin{array}{l}1.447 * * * \\
(0.549)\end{array}$ & $\begin{array}{l}1.343 * * \\
(0.559)\end{array}$ & $\begin{array}{l}1.380 * * \\
(0.571)\end{array}$ \\
\hline $\mathrm{MBC}$ & & $\begin{array}{c}0.989 \\
(0.643)\end{array}$ & $\begin{array}{c}1.003 \\
(0.646)\end{array}$ & $\begin{array}{c}1.146^{*} \\
(0.617)\end{array}$ & $\begin{array}{c}1.357^{*} \\
(0.690)\end{array}$ & $\begin{array}{l}1.315 * \\
(0.666)\end{array}$ \\
\hline Muslim & & & $\begin{array}{l}1.007^{* *} \\
(0.415)\end{array}$ & $\begin{array}{l}1.508^{* * *} \\
(0.424)\end{array}$ & $\begin{array}{l}1.282 * * * \\
(0.464)\end{array}$ & $\begin{array}{c}0.662 \\
(0.594)\end{array}$ \\
\hline $\begin{array}{l}\text { Log total } \\
\text { income }\end{array}$ & & & & $\begin{array}{l}0.434 * * \\
(0.191)\end{array}$ & $\begin{array}{l}0.400 * * \\
(0.198)\end{array}$ & $\begin{array}{l}0.331 * \\
(0.199)\end{array}$ \\
\hline AIADMK Party & & & & & $\begin{array}{c}0.462 \\
(0.422)\end{array}$ & $\begin{array}{c}0.745 * \\
(0.447)\end{array}$ \\
\hline Motive: polit & & & & & & $\begin{array}{l}2.126^{* * *} \\
(0.910)\end{array}$ \\
\hline $\begin{array}{l}\text { Motive: } \\
\text { reserved }\end{array}$ & & & & & & $\begin{array}{c}-0.937^{*} \\
(0.477)\end{array}$ \\
\hline Motive: other & & & & & & $\begin{array}{c}0.393 \\
(0.466)\end{array}$ \\
\hline Constant & $\begin{array}{l}10.029 * * * \\
(1.615)\end{array}$ & $\begin{array}{l}9.649 * * * \\
(1.623)\end{array}$ & $\begin{array}{l}9.654 * * * \\
(1.628)\end{array}$ & $\begin{array}{l}5.865 * * \\
(2.467)\end{array}$ & $\begin{array}{l}5.850 * * \\
(2.442)\end{array}$ & $\begin{array}{l}6.188 * * \\
(2.415)\end{array}$ \\
\hline Observations & 144 & 144 & 144 & 142 & 141 & 141 \\
\hline R-squared & 0.458 & 0.471 & 0.472 & 0.479 & 0.487 & 0.511 \\
\hline
\end{tabular}

Notes: Robust standard errors in parentheses. Schooling level indicates highest level completed, $\mathrm{MBC}=$ most backward caste, AIADMK indicates affiliation with the AIADMK party, and 'Motive' indicates presidents' motives for running for office (polit=nominated by political party, reserved $=$ seat was reserved). Two observations are lost when the income variable is added due to two presidents with zero income.

$* * * \mathrm{p}<0.01$

$* * \mathrm{p}<0.05$.

$* \mathrm{p}<0.1$.

Source: Authors' analysis based on data described in text. 
Table 6. GP Presidents' Contact with Higher-Level Panchayat Officials

\begin{tabular}{lccl}
\hline & $\begin{array}{c}\text { Unreserved } \\
\text { GPs }\end{array}$ & $\begin{array}{c}\text { GPs Reserved for } \\
\text { Women }\end{array}$ & Difference \\
\hline $\begin{array}{l}\text { Contact with Block Development Officer } \\
\text { (BDO) }\end{array}$ & 2.908 & 2.413 & $0.495^{* * * *}$ \\
$\begin{array}{l}\text { Contact with Panchayat Union Chairman } \\
\text { (PUC) }\end{array}$ & 2.214 & 0.717 & $\begin{array}{l}1.072 \\
\text { Contact with District Panchayat Chairman }\end{array}$ \\
$\begin{array}{l}\text { (DPC) } \\
\text { (DU* }\end{array}$ & 1.306 & 0.391 & 0.129 \\
\end{tabular}

Note: Standard errors from a t-test of a difference in means are shown in italics.

'Contact with . . .' refers to the frequency of contact between the GP president and the listed official, as answered by the GP president in an interview. $0=$ 'Never,' $1=$ 'Rarely,' 2 = 'Sometimes,' $3=$ 'Frequently.'

$\because * \mathrm{p}<.01$.

Source: Authors' analysis based on data described in text.

(BDO), followed by the Panchayat Union Chairman (PUC), both of whom are officials at the intermediate level (Union) of the three-tier panchayat system. Contact with the District level is largely left to the Union. This is supported by our data: most contact is with the BDO, followed by the PUC. Both men and women GP presidents have much less contact with the District Panchayat Chairman (DPC), though the difference between men and women is still statistically significant. Thus, women GP presidents' significantly lower contact with higher-level officials-particularly at the Union level-provides another reason to suspect that they may have difficulty providing public goods for their constituency.

A natural question is whether these differences between men and women result from more experience by male presidents vis-à-vis female presidents. However, there are very few incumbents on both sides: only nine percent for women (four of 46 seats) and 12 percent for men (12 of 98 seats). Given only 16 experienced presidents in the dataset, the prospects for analysis are limited. However, we can confidently say that differences in experience are not driving the knowledge and contact differences between men and women presidents. Eliminating the 16 experienced presidents does not change the findings or the significance of the difference between men and women in terms of their contact with the higher-level officials, and it does not impact the strong correlation between gender and test scores (Table 5). Interestingly, the 16 experienced presidents have statistically significantly (1) higher knowledge test scores (on average, they answer two more questions correctly) and (2) more contact with the PUC compared to non-experienced presidents, providing some evidence that experience as a GP president does matter. However, differences in experience alone do not drive the differences between men and women. 


\section{Preferences}

We examine male and female preferences for public goods to determine whether presidents provide public goods according to their preferences. We estimate preferences using survey questions posed to 270 citizens (139 men and 131 women) randomly sampled in 27 villages over the three districts surveyed in Tamil Nadu. One question asks citizens to list up to five infrastructure items needed in their village. All persons of a given GP were surveyed from the same village, so no bias resulted from different provision in different villages of the GP. More than 30 different responses were given by the 270 citizens. $^{23}$

The results of chi-square tests of whether men's and women's preferences are drawn from different distributions are presented in the supplemental appendix (Table S1.3). Regardless of whether we conduct the test on all responses given by the group or the top five or 10 responses within the group, we cannot reject the null hypothesis that men's and women's preferences are drawn from the same distribution. ${ }^{24}$ This finding is in contrast to Chattopadhyay and Duflo (2004), who find differences in preferences for public goods in Rajasthan and West Bengal using a chi-square test, illustrating the importance of context-specific analyses. We also provide individual $t$-tests of the percentage of men and women that listed each infrastructure item (Table S1.4). There are no statistically significant differences, with the exception of veterinary services (mentioned by only 14 citizens). Of the top 11 areas mentioned, we investigate eight in our public goods analysis. We do not have good data on 'drainage' or 'group houses,' and the GP president does not have much control over 'companies and industries. ${ }^{25}$

\section{Results}

We next compare changes in public goods from 1991 to 2005 across unreserved and reserved GPs. Regardless of whether there is a gender difference in preferences, we are still interested in examining whether men and women provide different amounts of public goods because there are strong reasons to suspect there may be a difference:

1) Women's low scores on the knowledge test suggest that women might not be able to function well as GP presidents and thus might have lower public goods provision.

2) Women's minimal interaction with higher-level officials suggests that women might have lower public goods provision, at least for those goods that require coordination and/or support from higher levels of the panchayat system.

23. A list of all responses is given in the supplemental appendix (Table S1.2).

24. In a previous version of this paper, we counted only the first three-instead of all five-responses given by individuals, thinking that this indicated individuals' strongest opinions. However, after discussions with the research team, we determined that it was erroneous to omit any responses. All responses are thus counted in this analysis.

25. We use the top 11 responses instead of 10 because "Streetlights" and "Independent pipeline/toilet connections" are tied as the tenth most mentioned items of infrastructure. 
TABLE 7. Basic DID Estimation

\begin{tabular}{|c|c|c|c|c|c|c|c|}
\hline \multirow[b]{2}{*}{ Variable } & \multicolumn{2}{|c|}{ Reserved GPs } & \multicolumn{2}{|c|}{ Unreserved GPs } & \multicolumn{2}{|c|}{ Time Period Difference } & \multirow[b]{2}{*}{ DID Estimator } \\
\hline & Mean 1991 & Mean 2005 & Mean 1991 & Mean 2005 & Diff Reserved & Diff Unreserved & \\
\hline Health (Composite Measure) & $\begin{array}{c}0.037 \\
(1.029)\end{array}$ & $\begin{array}{c}0.047 \\
(0.841)\end{array}$ & $\begin{array}{r}-0.017 \\
(0.986)\end{array}$ & $\begin{array}{r}-0.022 \\
(1.065)\end{array}$ & $\begin{array}{c}0.010 \\
{[0.075]}\end{array}$ & $\begin{array}{c}-0.005 \\
{[0.082]}\end{array}$ & $\begin{array}{c}0.014 \\
{[0.110]}\end{array}$ \\
\hline Schools & $\begin{array}{c}2.261 \\
(1.219)\end{array}$ & $\begin{array}{c}2.609 \\
(1.291)\end{array}$ & $\begin{array}{c}2.582 \\
(1.592)\end{array}$ & $\begin{array}{c}3.622 \\
(2.375)\end{array}$ & $\begin{array}{l}0.348 * * * \\
{[0.095]}\end{array}$ & $\begin{array}{l}1.041 * * * \\
{[0.162]}\end{array}$ & $\begin{array}{c}-0.693 * * \% \\
{[0.187]}\end{array}$ \\
\hline Distance $(\mathrm{km})$ to nearest concrete road & $\begin{array}{c}0.364 \\
(0.297)\end{array}$ & $\begin{array}{c}0.249 \\
(0.326)\end{array}$ & $\begin{array}{c}0.447 \\
(0.593)\end{array}$ & $\begin{array}{c}0.253 \\
(0.401)\end{array}$ & $\begin{array}{c}-0.115 * * \\
{[0.026]}\end{array}$ & $\begin{array}{c}-0.193 * * \\
{[0.035]}\end{array}$ & $\begin{array}{c}0.078^{*} \\
{[0.044]}\end{array}$ \\
\hline Bus and minibus trips & $\begin{array}{c}7.674 \\
(7.457)\end{array}$ & $\begin{array}{c}12.761 \\
(13.820)\end{array}$ & $\begin{array}{c}8.643 \\
(10.346)\end{array}$ & $\begin{array}{c}13.439 \\
(14.693)\end{array}$ & $\begin{array}{l}5.087 * * * \\
{[1.330]}\end{array}$ & $\begin{array}{l}4.796 * * * \\
{[0.611]}\end{array}$ & $\begin{array}{c}0.291 \\
{[1.452]}\end{array}$ \\
\hline Streetlights & $\begin{array}{c}52.870 \\
(47.842)\end{array}$ & $\begin{array}{c}86.370 \\
(54.832)\end{array}$ & $\begin{array}{c}60.551 \\
(45.493)\end{array}$ & $\begin{array}{l}107.367 \\
(75.970)\end{array}$ & $\begin{array}{l}33.500 * * * \\
{[3.931]}\end{array}$ & $\begin{array}{l}46.816 * * * \\
{[4.308]}\end{array}$ & $\begin{array}{c}-13.316 * * \\
{[5.804]}\end{array}$ \\
\hline Public toilets & $\begin{array}{c}0.304 \\
(0.465)\end{array}$ & $\begin{array}{c}1.478 \\
(1.472)\end{array}$ & $\begin{array}{c}0.459 \\
(0.501)\end{array}$ & $\begin{array}{c}1.878 \\
(1.676)\end{array}$ & $\begin{array}{l}1.174 * * * \\
{[0.224]}\end{array}$ & $\begin{array}{l}1.418 * * * \\
{[0.172]}\end{array}$ & $\begin{array}{c}-0.244 \\
{[0.281]}\end{array}$ \\
\hline Common taps & $\begin{array}{c}48.178 \\
(54.542)\end{array}$ & $\begin{array}{c}96.587 \\
(84.957)\end{array}$ & $\begin{array}{c}44.133 \\
(55.410)\end{array}$ & $\begin{array}{l}78.796 \\
(69.024)\end{array}$ & $\begin{array}{l}50.111 * * * \\
{[8.914]}\end{array}$ & $\begin{array}{l}34.663 * * * \\
{[4.646]}\end{array}$ & $\begin{array}{l}15.448 \\
{[9.975]}\end{array}$ \\
\hline $\mathrm{HH}$ toilet connection & $\begin{array}{c}7.652 \\
(10.861)\end{array}$ & $\begin{array}{c}94.348 \\
(101.868)\end{array}$ & $\begin{array}{c}10.980 \\
(17.776)\end{array}$ & $\begin{array}{c}146.296 \\
(235.716)\end{array}$ & $\begin{array}{l}86.696 * * * \\
{[15.244]}\end{array}$ & $\begin{array}{l}135.316 * * \\
{[23.920]}\end{array}$ & $\begin{array}{c}-48.621 \% \\
{[28.273]}\end{array}$ \\
\hline $\mathrm{HH}$ drinking water connection & $\begin{array}{c}16.891 \\
(47.532)\end{array}$ & $\begin{array}{c}90.196 \\
(100.499)\end{array}$ & $\begin{array}{c}19.061 \\
(45.800)\end{array}$ & $\begin{array}{c}142.745 \\
(167.372)\end{array}$ & $\begin{array}{l}73.304 * * * \\
{[12.427]}\end{array}$ & $\begin{array}{l}123.684 * * * \\
{[16.613]}\end{array}$ & $\begin{array}{c}-50.379 * \\
{[20.667]}\end{array}$ \\
\hline
\end{tabular}

Notes: Standard deviations are given in (parentheses).

Robust Standard errors are given in [brackets].

$* * * \mathrm{p}<0.01$

$* * \mathrm{p}<0.05$

$* \mathrm{p}<0.10$.

Source: Authors' analysis based on data described in text. 
We have data on many measures of public goods provision in the GPs, but we restrict this analysis to public goods that coincide with citizens' most preferred items of infrastructure, as discussed earlier. We use 10 public goods measures (covering eight areas of public goods), which are described in Appendix A2. These variables reflect changes in physical infrastructure during a president's time in office as well as changes in outcomes. For example, we use data on the number of schools to measure investment in schools and education, whereas we use data on the percentage of children given various immunizations as an outcome measure of investments in health. These measures are used in a basic DID estimation strategy (Equation 2), with results given in Table 7.

Of our 10 measures of public goods, five measures exhibit no statistically significant difference in provision between male and female presidents: children's health, bus trips, public toilets, borewells, and common taps. Of these five, the point estimates are quite small in all cases with the exception of common taps. For the other five measures, we find that GPs with and without a woman in a reserved president seat had statistically significantly different changes in provision from 1991 to 2005: women-reserved GPs added fewer schools, fewer household drinking water connections, fewer household toilet connections, and fewer operational streetlights, and the distance to the nearest concrete road was farther away. In all cases, the change in the level of public goods indicates lower provision in women-reserved GPs versus unreserved GPs. Although we will not place too much emphasis on precise numbers, these differences are of non-trivial magnitude. The results suggest that women-reserved GPs had close to one fewer school, 13 fewer operational streetlights, 49 fewer household toilets, and 50 fewer household drinking water connections, and the nearest concrete road was 0.08 kilometers farther away compared with unreserved GPs.

Table 8 shows the results of a DID estimation with the following covariates added (Equation 3): the number of villages that compose the GP, GP female and SC population ratios in 1991, log of GP total population in 1991, a dummy variable indicating a president's membership in the AIADMK political party, ${ }^{26}$ log of total land area of the GP in 1991, the knowledge test score, and a dummy variable indicating low $(=0)$ or high $(=1)$ frequency of contact with the Block Development Officer, an important official situated one level above the GP. ${ }^{27}$ These covariates control for relevant characteristics that could influence public goods provision if they are trending differently over time.

The results suggest that fewer schools and roads were created in femalereserved GPs, and these differences are non-trivial. For the remaining measures

26. The party in power in Tamil Nadu generally alternates between the DMK (Dravida Munnetra Kazhagam) and AIADMK (All India Anna Dravida Munnetra Kazhagam) parties. In 2005, the AIADMK was in power from the 2001 elections. For GP-level elections, the de jure rules state that candidates cannot run on a political party. However, de facto, their party affiliation does play a role.

27. We also did this for contact with the Panchayat Union Chairman (PUC) and District Panchayat Chairman (DPC); the results are similar. We report only the results using BDO to save space. Additionally, the $\mathrm{BDO}$ is arguably the most important higher-level official with whom to be in touch. 
TABle 8. DID Estimation with Covariates

\begin{tabular}{|c|c|c|c|c|c|c|c|c|c|c|}
\hline & $\begin{array}{c}\text { Health } \\
\text { (Composite } \\
\text { Measure) }\end{array}$ & Schools & $\begin{array}{c}\text { Distance } \\
(\mathrm{km}) \text { to } \\
\text { nearest } \\
\text { concrete } \\
\text { road }\end{array}$ & $\begin{array}{l}\text { Bus and } \\
\text { minibus } \\
\text { trips }\end{array}$ & Streetlights & $\begin{array}{l}\text { Public } \\
\text { toilets }\end{array}$ & $\begin{array}{l}\text { Common } \\
\text { taps }\end{array}$ & $\begin{array}{c}\text { Number of } \\
\text { borewells }\end{array}$ & $\begin{array}{l}\text { HH toilet } \\
\text { connection }\end{array}$ & $\begin{array}{c}\mathrm{HH} \\
\text { drinking } \\
\text { water } \\
\text { connection }\end{array}$ \\
\hline $\begin{array}{l}\text { Woman } \\
\text { Res*2005 }\end{array}$ & $\begin{array}{l}-0.104 \\
(0.164)\end{array}$ & $\begin{array}{l}-0.840 * * * \\
(0.252)\end{array}$ & $\begin{array}{l}0.106 * \\
(0.062)\end{array}$ & $\begin{array}{l}0.357 \\
(1.677)\end{array}$ & $\begin{array}{l}-4.291 \\
(7.982)\end{array}$ & $\begin{array}{l}0.121 \\
(0.371)\end{array}$ & $\begin{array}{l}17.938 \\
(13.279)\end{array}$ & $\begin{array}{l}0.423 \\
(0.733)\end{array}$ & $\begin{array}{l}-20.315 \\
(32.610)\end{array}$ & $\begin{array}{l}-45.331 \\
(29.094)\end{array}$ \\
\hline 2005 & $\begin{array}{l}-3.415 \\
(2.440)\end{array}$ & $\begin{array}{l}-7.421 * * \\
(3.678)\end{array}$ & $\begin{array}{l}0.350 \\
(0.798)\end{array}$ & $\begin{array}{l}-10.881 \\
(18.586)\end{array}$ & $\begin{array}{l}11.068 \\
(160.442)\end{array}$ & $\begin{array}{l}-5.383 \\
(6.728)\end{array}$ & $\begin{array}{l}72.311 \\
(191.438)\end{array}$ & $\begin{array}{l}-14.983 * \\
(7.950)\end{array}$ & $\begin{array}{l}-270.358 \\
(480.199)\end{array}$ & $\begin{array}{l}-248.201 \\
(553.813)\end{array}$ \\
\hline \# Vills in GP & $\begin{array}{l}-0.016 \\
(0.020)\end{array}$ & $\begin{array}{l}0.050 * * \\
(0.020)\end{array}$ & $\begin{array}{l}0.008 \\
(0.006)\end{array}$ & $\begin{array}{l}0.144 \\
(0.152)\end{array}$ & $\begin{array}{l}2.191 \\
(1.831)\end{array}$ & $\begin{array}{l}0.014 \\
(0.035)\end{array}$ & $\begin{array}{l}-1.335 \\
(1.111)\end{array}$ & $\begin{array}{l}0.007 \\
(0.087)\end{array}$ & $\begin{array}{l}10.228 \\
(12.132)\end{array}$ & $\begin{array}{l}1.978 \\
(4.877)\end{array}$ \\
\hline $\begin{array}{c}\text { SC Pop Ratio } \\
\quad(1991)\end{array}$ & $\begin{array}{l}0.917 * * \\
(0.407)\end{array}$ & $\begin{array}{l}0.703 \\
(1.179)\end{array}$ & $\begin{array}{l}0.081 \\
(0.173)\end{array}$ & $\begin{array}{l}-1.620 \\
(3.551)\end{array}$ & $\begin{array}{l}-5.539 \\
(19.341)\end{array}$ & $\begin{array}{l}-0.903 \\
(0.888)\end{array}$ & $\begin{array}{l}-17.820 \\
(24.746)\end{array}$ & $\begin{array}{l}1.968 \\
(1.671)\end{array}$ & $\begin{array}{l}210.418 * * \\
(82.553)\end{array}$ & $\begin{array}{l}150.727 \\
(93.549)\end{array}$ \\
\hline $\begin{array}{c}\text { Female Pop } \\
\text { Ratio } \\
(1991)\end{array}$ & $\begin{array}{l}7.719 \\
(5.579)\end{array}$ & $\begin{array}{l}9.296 \\
(5.842)\end{array}$ & $\begin{array}{l}1.014 \\
(1.261)\end{array}$ & $\begin{array}{l}11.613 \\
(31.666)\end{array}$ & $\begin{array}{l}-90.043 \\
(270.071)\end{array}$ & $\begin{array}{l}9.404 \\
(9.512)\end{array}$ & $\begin{array}{l}-283.453 \\
(313.125)\end{array}$ & $\begin{array}{l}7.100 \\
(12.954)\end{array}$ & $\begin{array}{l}-1,481.365 \% \\
(887.773)\end{array}$ & $\begin{array}{l}-379.429 \\
(879.073)\end{array}$ \\
\hline $\begin{array}{l}\text { AIADMK } \\
\text { Party }\end{array}$ & $\begin{array}{l}0.160 \\
(0.117)\end{array}$ & $\begin{array}{l}0.387^{*} \\
(0.211)\end{array}$ & $\begin{array}{l}0.015 \\
(0.052)\end{array}$ & $\begin{array}{l}1.004 \\
(1.199)\end{array}$ & $\begin{array}{l}7.576 \\
(5.611)\end{array}$ & $\begin{array}{l}0.007 \\
(0.331)\end{array}$ & $\begin{array}{l}15.674 \% \\
(8.220)\end{array}$ & $\begin{array}{l}-0.050 \\
(0.505)\end{array}$ & $\begin{array}{l}13.432 \\
(29.490)\end{array}$ & $\begin{array}{l}19.973 \\
(20.940)\end{array}$ \\
\hline $\begin{array}{l}\text { Log Total } \\
\text { Pop (1991) }\end{array}$ & $\begin{array}{l}-0.138 \\
(0.175)\end{array}$ & $\begin{array}{l}0.764 * * * \\
(0.219)\end{array}$ & $\begin{array}{l}-0.109 * \% \\
(0.044)\end{array}$ & $\begin{array}{l}0.555 \\
(0.997)\end{array}$ & $\begin{array}{l}4.192 \\
(5.432)\end{array}$ & $\begin{array}{l}-0.182 \\
(0.299)\end{array}$ & $\begin{array}{l}1.781 \\
(9.917)\end{array}$ & $\begin{array}{l}0.971 * * \\
(0.441)\end{array}$ & $\begin{array}{l}90.779 * * * \\
(25.816)\end{array}$ & $\begin{array}{l}73.802 * * * \\
(20.769)\end{array}$ \\
\hline $\begin{array}{l}\text { Log Total } \\
\text { Land } \\
(1991)\end{array}$ & $\begin{array}{l}0.088 \\
(0.101)\end{array}$ & $\begin{array}{l}-0.412^{* *} \\
(0.164)\end{array}$ & $\begin{array}{l}-0.058 * \\
(0.034)\end{array}$ & $\begin{array}{l}1.277 \\
(1.131)\end{array}$ & $\begin{array}{l}2.551 \\
(8.158)\end{array}$ & $\begin{array}{l}0.356 \\
(0.329)\end{array}$ & $\begin{array}{l}16.086 * \\
(8.598)\end{array}$ & $\begin{array}{l}0.740 \% \\
(0.412)\end{array}$ & $\begin{array}{l}38.009 * \\
(22.416)\end{array}$ & $\begin{array}{l}6.526 \\
(20.229)\end{array}$ \\
\hline Test Score & $\begin{array}{l}0.019 \\
(0.018)\end{array}$ & $\begin{array}{l}-0.043 \\
(0.039)\end{array}$ & $\begin{array}{l}0.011 \\
(0.008)\end{array}$ & $\begin{array}{l}-0.042 \\
(0.272)\end{array}$ & $\begin{array}{l}1.358 \\
(1.382)\end{array}$ & $\begin{array}{l}0.107 * \\
(0.060)\end{array}$ & $\begin{array}{l}0.740 \\
(1.720)\end{array}$ & $\begin{array}{l}0.064 \\
(0.100)\end{array}$ & $\begin{array}{l}-0.253 \\
(5.415)\end{array}$ & $\begin{array}{l}-0.280 \\
(3.416)\end{array}$ \\
\hline
\end{tabular}

(Continued) 
TABLE 8. Continued

\begin{tabular}{|c|c|c|c|c|c|c|c|c|c|c|}
\hline & $\begin{array}{c}\text { Health } \\
\text { (Composite } \\
\text { Measure) }\end{array}$ & Schools & $\begin{array}{l}\text { Distance } \\
(\mathrm{km}) \text { to } \\
\text { nearest } \\
\text { concrete } \\
\text { road }\end{array}$ & $\begin{array}{l}\text { Bus and } \\
\text { minibus } \\
\text { trips }\end{array}$ & Streetlights & $\begin{array}{l}\text { Public } \\
\text { toilets }\end{array}$ & $\begin{array}{l}\text { Common } \\
\text { taps }\end{array}$ & $\begin{array}{l}\text { Number of } \\
\text { borewells }\end{array}$ & $\begin{array}{l}\mathrm{HH} \text { toilet } \\
\text { connection }\end{array}$ & $\begin{array}{c}\mathrm{HH} \\
\text { drinking } \\
\text { water } \\
\text { connection }\end{array}$ \\
\hline Contact BDO & $\begin{array}{l}-0.407 \\
(0.263)\end{array}$ & $\begin{array}{l}0.778 * * * \\
(0.196)\end{array}$ & $\begin{array}{l}0.025 \\
(0.140)\end{array}$ & $\begin{array}{l}-4.678 \\
(7.364)\end{array}$ & $\begin{array}{l}-7.597 \\
(13.366)\end{array}$ & $\begin{array}{l}-0.367 \\
(0.244)\end{array}$ & $\begin{array}{l}-38.132 \\
(45.460)\end{array}$ & $\begin{array}{l}0.250 \\
(0.499)\end{array}$ & $\begin{array}{l}18.136 \\
(42.221)\end{array}$ & $\begin{array}{l}-126.937 \\
(137.387)\end{array}$ \\
\hline Constant & $\begin{array}{l}0.003 \\
(0.029)\end{array}$ & $\begin{array}{l}2.455 * * * \\
(0.053)\end{array}$ & $\begin{array}{l}0.421 * * * \\
(0.012)\end{array}$ & $\begin{array}{l}8.308 * * * \\
(0.293)\end{array}$ & $\begin{array}{l}58.203 * * * \\
(1.518)\end{array}$ & $\begin{array}{l}0.413 * * * \\
(0.068)\end{array}$ & $\begin{array}{l}45.032 \% * * \\
(2.055)\end{array}$ & $\begin{array}{l}3.415 * * * \\
(0.127)\end{array}$ & $\begin{array}{l}9.986 \\
(7.239)\end{array}$ & $\begin{array}{l}18.497 * * * \\
(5.584)\end{array}$ \\
\hline Observations & 286 & 286 & 286 & 286 & 286 & 286 & 285 & 276 & 286 & 286 \\
\hline R-squared & 0.117 & 0.412 & 0.330 & 0.364 & 0.614 & 0.436 & 0.448 & 0.579 & 0.481 & 0.475 \\
\hline $\begin{array}{l}\text { Number of } \\
\text { GPs }\end{array}$ & 143 & 143 & 143 & 143 & 143 & 143 & 143 & 138 & 143 & 143 \\
\hline
\end{tabular}

Note: Robust standard errors (clustered by village) in parentheses.

'Contact BDO' is a dummy variable that is equal to 1 when a president's contact with the BDO is "high." Here, "high" contact means the president stated they were in contact "sometimes' or "frequently" with the BDO and "low" contact means the president replied "low" or "never."

$\because * \mathrm{p}<0.01$.

$* \mathrm{p}<0.05$.

$* \mathrm{p}<0.1$.

Source: Authors' analysis based on data described in text. 
of public goods, we find no statistically significant difference in provision between reserved and unreserved GPs. However, the point estimates on the effect of having a woman in a reserved seat remain large, of the same sign, and have comparable coefficients vis-à-vis the basic DID findings in the cases of streetlights, household toilet connections, and household drinking water connections, all indicating lower levels of provision in women-reserved GPs. Only in the case of common taps is the point estimate suggestive that women presidents in reserved GPs are providing more of this public good, although this is statistically insignificant in all specifications. Thus, overall, we find strong evidence that female presidents in Tamil Nadu's reserved GPs provide fewer schools and roads and weak evidence that they provide less of some other goods as well. We find almost no evidence of women in reserved seats doing better in any aspect of GP public goods provision.

Including presidents' test scores and frequency of contact with the BDO reveals that higher test scores and more frequent contact are positively correlated with public goods provision. Although these variables are significant in only a few cases, this is likely due to inflated standard errors from the relatively high correlation between test scores, frequency of contact, and a GP's reservation status. Indeed, the correlation between reservation status and test scores is 61 percent, and it is 50 percent between reservation status and frequency of contact with the BDO.

As expected, a larger population is positively correlated with the provision of some public goods: household toilet and water connections, schools, borewells, and roads. We also find that having more villages that compose a GP is associated with greater provision of schools, which coincides with our intuition. Additionally, affiliation with the AIADMK party is associated with more common taps and more schools.

\section{Further Checks}

As discussed earlier, a regression discontinuity design is ideal in many ways. However, given data restrictions, we do not pursue RD as the main analysis. We instead present a simple RD analysis in the supplemental Appendix S3. The results show a clear gap in the case of schools and smaller gaps for roads and household drinking water connections, although none of the results is statistically significant. This is likely due to too few observations when we consider data only within a bandwidth around the discontinuity.

Given concerns that experienced presidents might be driving the results, we also duplicate the DID with covariates analysis excluding the 16 presidents in their second term in office. Our findings hold and, in fact, are stronger: in addition to schools and roads, there is some evidence that women presidents provide fewer household toilet and drinking water connections, which are also highercost public goods that require coordination with higher-level officials such as the BDO and PUC (Table S1.5). 


\section{DISCUSSION}

Our findings suggest that for at least some public goods, presidents in womenreserved GPs are providing fewer public goods relative to unreserved GPs. There is evidence that these women are performing similarly to men in some aspects, but there is almost no evidence that they are providing more of any public good.

Given women's apparent lack of knowledge regarding the GP coupled with their limited contact with block- and district-level officials, it is not surprising that we find women presidents in reserved GPs providing fewer public goods compared to male presidents. We can identify two pathways through which the knowledge test helps to explain women's poorer performance. If the knowledge test is an accurate measure of a president's ability, then the test results indicate that women are of lower ability. We would thus expect to see lower public goods provision in female-reserved GPs. If the knowledge test is not a good measure of ability and one could be a successful president despite being unable to correctly answer most questions on our knowledge test, the lower test scores are still indicative of something. Presidents took this knowledge test, consisting of basic questions about the panchayat, in the fourth year of their presidencies. If a sitting president is active in their position, he or she should be able to answer most questions correctly, having encountered those issues during the four years in office. The poor test results of female presidents at least indicate a lack of engagement with their political office. Therefore, if a low test score indicates a lack of participation in GP activities by the president, we would again expect to see lower public goods provision by presidents with lower test scores.

Next, we consider schools and roads, two public goods for which there exists a robust difference in provision between reserved and unreserved GPs. Our data suggest that over the course of the first reservation cycle in Tamil Nadu GPs, there were significantly more schools created in unreserved versus womenreserved GPs. The creation of a new school requires substantial coordination with higher-level officials. Thus, this finding is consistent with reserved women presidents' clear lack of engagement with higher-level officials. A similar story holds for roads, where our results show that the distance to the nearest concrete road is farther in women-reserved GPs. Additionally, there are fewer household drinking water and toilet connections and fewer operational streetlights. These are only significant in the basic DID, although the sign and size of the point estimates are consistent in the DID with covariates. Household connections are another GP public good that require coordination with higher-level officials because part of their funding is provided by the panchayat (hence their inclusion in our analysis of public goods). As a comparison, vaccinations are completely out of the control of the GP president, and we see no difference in vaccinations to children measured by the HEALTH variable. To the best of our knowledge, these findings are new in the literature.

Our research underscores the importance of context in empirical studies. The findings in some previous research are compelling and provide evidence of women's 
reservations doing good for women in parts of West Bengal (Chattopadhyay and Duflo 2004; Beaman et al. 2009; Beaman et al. 2012). However, these results do not represent the status of women's reservations throughout India's GPs. Mathew (2000a) reviews the history of local governance throughout India, showing the differences in Indian states' experiences with decentralized governance. West Bengal, for example, is often cited as India's panchayat success story and has had regular elections to the panchayats since 1978 (Ghosh 2000). Additionally, West Bengal amended its state panchayat act in 1992-before India's $73^{\text {rd }}$ Amendment was passed-to provide for one-third reservation of all seats in all three levels of panchayats for women (although there was no explicit reservation for the position of president) (Ghosh 2000). In accordance with the $73^{\text {rd }}$ Amendment, West Bengal amended its state panchayat act to reserve onethird of GP presidential seats for women. Of its own accord, West Bengal further amended its panchayat system to reserve one-third of vice-president positions for women as well. Thus, by the late 1990s, women in West Bengal's panchayats had significant experience in panchayats in addition to participating in panchayats that had been successful since the late 1970 s.

We contrast West Bengal's experience with that of Tamil Nadu. Tamil Nadu had reasonably successful local governance under British rule (Aram and Palanithurai 2000). After India's independence in 1947, Tamil Nadu's 1958 panchayat act led to what was considered a rather successful panchayat system until about 1970 (Aram and Palanithurai 2000). However, after the 1970 panchayat elections, Tamil Nadu's elections were postponed until 1986. From then until Tamil Nadu's Panchayat Act of 1994, local governance was very different than it is now and was very different from the experience of West Bengal. For example, prior to the 1994 Act, Tamil Nadu had a district-level panchayat with minimal power, whereas most power was at the block level.

Thus, the performance of panchayats and women in panchayats certainly varies by state given their diverse histories and experiences with panchayat institutions. Although the $73^{\text {rd }}$ Amendment set forth a constitutionally mandated structure of panchayats for all states, the rich history of local governance preceding the $73^{\text {rd }}$ Amendment has surely influenced the functioning of panchayats following the $73^{\text {rd }}$ Amendment. It is this important notion that we wish to emphasize in our findings of public goods provision by women presidents in women-reserved GPs in Tamil Nadu.

\section{Concluding Remarks}

Given the rising prevalence of gender reservations and quotas in developing country governments, our study seeks to better understand the role of gender in public goods provision in a specific setting. Using data from 144 village-level governments in Tamil Nadu, we investigate women's reservations at the GP level and evaluate the role of presidents' gender on local public goods provision. For some public goods, provision is similar among female and male presidents. 
However, we find very suggestive evidence that public goods provision by women presidents in women-reserved GPs is lower than that of their male counterparts. In particular, we find strong evidence that GPs with women-reserved president seats created fewer schools and roads than unreserved GPs during the period under study. We find weak evidence that women are providing fewer streetlights and household drinking water and toilet connections. These findings are correlated with strong evidence of women's lack of interaction with higherlevel government officials and women's low knowledge of the GP.

These findings contribute to the literature on women's reservations in India by highlighting that the GP reservation system may be falling short in providing knowledge of the GP to women who are new to political office and in providing a pathway for connections between women GP presidents and higher-level officials. To our knowledge, this is the first study to document a clear lack of communication between women GP presidents and higher-level officials at the block and district levels and to link this lack of communication to demonstrably worse outcomes for the GP, particularly in terms of the provision of schools and roads.

This study highlights the need-in at least some parts of India-to improve women's preparedness for the office of GP president and their connections while in office. Increased or more targeted training for female presidents may help to improve their knowledge of the panchayat system and their understanding of their role as GP president and in panchayati raj in general, thus improving their performance of official duties and the procurement of funds and public goods for their GP. Indeed, many of the female presidents interviewed for this study complained that training was given either too late or not at all and that they were given an overwhelmingly large amount of paperwork to read and understand without accompanying support. This suggests that more timely and adequate training for female presidents may further support their role in Indian governance and help them to better achieve one of the main goals of women's reservation policies: having pro-women, pro-family, pro-children advocates in government.

Our findings also highlight the importance of context in empirical analyses. Previous findings in West Bengal show that women's reservations have the potential to address the needs of women. Our findings in Tamil Nadu show that this does not happen automatically. We need not wait 30 years for women in Tamil Nadu to learn to make the most out of their positions in office. Our study shows that there is a lack of knowledge among women GP presidents and a weak relationship between women GP presidents and higher-level officials. We do not take our findings to represent the state of women's reservations across India. We do, however, interpret our findings as representative of women's reservations in at least some parts of Tamil Nadu and as evidence that the implementation of women's reservations in India needs further improvement to realize the potential of women's representation in government. 


\section{APPENDIX}

\section{A 1. The GP Knowledge Test}

The 19 questions asked of every GP president in our survey are given below.

1. Which Amendment recognizes the village panchayat as local self-government?

2. What is the reservation percentage for women in the new panchayat act?

3. How many tiers does the local self-government have?

4. Does the district collector have the power to dissolve the village panchayat?

5. If the village panchayat is dissolved, within what time limit should an election be conducted?

6. Who has the power to remove the panchayat president?

7. What is the minimum population required for a village panchayat?

8. Who advises the state government on the release and allocation of funds to the panchayat?

9. What is the minimum and maximum number of members in a village panchayat?

10. If no women participants are elected in the village panchayat, how does the selection of women members take place?

11. How many sub-committees are formed in the village panchayat?

12. Which committee is responsible for the planning of the district as a whole?

13. What is the tenure of the village panchayat?

14. The panchayat audit is done by whom?

15. What is the minimum percentage of attendance required for conducting the village Gram Sabha meeting?

16. How many times should the village Gram Sabha meeting be conducted in a year?

17. How will you inform the public regarding the village Gram Sabha meeting?

18. Who initiates the resolution during the village Gram Sabha meeting: president/vice president/village people?

19. What is the maximum amount a panchayat can utilize for village development works without any permission from higher officials? 


\section{A2. The Public Goods Measures}

Eight (of the top 11) public goods mentioned in the citizen survey are listed on the left, with the corresponding public goods data used in our analysis on the right.

\begin{tabular}{|c|c|}
\hline Drinking Water: & Number of borewells; Number of common taps \\
\hline Health/Hospital: & $\begin{array}{l}\text { Composite measure }^{\mathrm{a}} \text { of the percentage of children given } \\
\text { immunizations for DPT, BCG, OPV, Measles, Tetanus- } \\
\text { Toxoid }\end{array}$ \\
\hline Roads: & Distance to nearest concrete road (in kilometers) \\
\hline School/Education: & Number of schools \\
\hline Sanitation: & Number of public toilets \\
\hline Buses: & Number of bus $\&$ minibus trips \\
\hline Individual Pipeline/ & Number of households with a drinking water connection; \\
\hline Toilet Connection: & Number of households with a toilet \\
\hline Streetlights: & Number of operational streetlights \\
\hline
\end{tabular}

\section{REFERENCES}

Anand, G., and A. Sharma. 2011. "For India's Lowest Castes, Path Forward Is 'Backward'." The Wall Street Journal, December 9.

Aram, M., and G. Palanithurai. 2000. “Tamil Nadu.” In G. Mathew, ed., Status of Panchayati Raj in the States and Union Territories of India, 270-82. New Delhi: Published for the Institute of Social Sciences by Concept Publishing Company.

Ban, R., and V. Rao. 2008. "Tokenism or Agency? The Impact of Women's Reservations on Village Democracies in South India." Economic Development and Cultural Change 56 (3) : 501-30.

Bardhan, P., D. Mookherjee, and M. P. Torrado. 2005. "Impact of Reservations of Panchayat Pradhans on Targeting in West Bengal.” Bureau for Research in Economic Analysis of Development (BREAD) Working Paper No. 104.

Bardhan, P. K., D. Mookherjee, and M. P. Torrado. 2010. "Impact of Political Reservations in West Bengal Local Governments on Anti-Poverty Targeting." Journal of Globalization and Development $1(1): 1-38$.

Beaman, L., R. Chattopadhyay, E. Duflo, R. Pande, and P. Topalova. 2009. "Powerful Women: Does Exposure Reduce Bias?” Quarterly Journal of Economics 124 (4) : 1497-540.

Beaman, L., E. Duflo, R. Pande, and P. Topalova. 2010. "Political Reservation and Substantive Representation: Evidence from Indian Village Councils” In S. Bery, B. Bosworth, and A. Panagariya, eds., India Policy Forum, 2010, Vol. 7, 159-202. Washington, DC and New Delhi: Brookings Institution Press and The National Council of Applied Economic Research.

2012. "Female Leadership Raises Aspirations and Educational Attainment for Girls: A Policy Experiment in India." Science 335 (6068) : 582-6.

Chattopadhyay, R., and E. Duflo. 2004. "Women as Policy Makers: Evidence from a Randomized Experiment in India." Econometrica 72 (5) : 1409-43.

a. The 'composite measure' is a weighted average of all of the factors listed in the group. The weighted values were calculated using a factor analysis procedure. 
Duflo, E., and P. Topalova. 2004. "Unappreciated Service: Performance, Perceptions, and Women Leaders in India." Mimeo. Cambridge, MA, Massachusetts Institute of Technology. http://www. povertyactionlab.org/sites/default/files/publications/66_Duflo_Topalova_Unappreciated_Service.pdf

Faguet, J-P. 2004. “Does Decentralization Increase Government Responsiveness to Local Needs? Evidence from Bolivia." Journal of Public Economics 88 (3-4) : 867-93.

Ghosh, B. 2000. "West Bengal.” In G. Mathew, ed., Status of Panchayati Raj in the States and Union Territories of India, 306-19. New Delhi: Published for the Institute of Social Sciences by Concept Publishing Company.

Mathew, G., ed. 2000a. Status of Panchayati Raj in the States and Union Territories of India. New Delhi: Published for the Institute of Social Sciences by Concept Publishing Company.

- 2000b. "Panchayati Raj in India-An Overview." In G. Mathew, ed., Status of Panchayati Raj in the States and Union Territories of India, 3-22. New Delhi: Published for the Institute of Social Sciences by Concept Publishing Company.

Rajaraman, I., and M. Gupta. 2012. "Public Expenditure Choices and Gender Quotas.” Indian Growth and Development Review 5 (2) : 108-30.

World Bank. 2001. "Engendering Development Through Gender Equality in Rights, Resources, and Voice.” Policy Research Report 21776. World Bank, Policy Research Department, Washington, DC.

Zhang, T., and H. Zhou. 1998. "Fiscal Decentralization, Public spending, and Economic Growth in China.” Journal of Public Economics 67 (2) : 221-40.

Zhang, X., S. Fan, L. Zhang, and J. Huang. 2004. "Local Governance and Public Goods Provision in Rural China." Journal of Public Economics 88 (12) : 2857-71. 